\title{
PENGARUH LINGKUNGAN TOKO TERHADAP IMPULSE BUYING DENGAN EMOSI POSITIF SEBAGAI VARIABEL INTERVENING
}

\author{
Regina Putri Maharanie $^{1}$, Suharyono $^{2}$, Edy Yulianto ${ }^{3}$ \\ Fakultas Ilmu Administrasi, Universitas Brawijaya, Malang, Indonesia \\ Email: ginamaharanie@gmail.com¹, sharyonofia@ub.ac.id², $\underline{\text { edy_y_fia@ub.ac.id }}$
}

\begin{abstract}
This study aimed to investigate the influence of independent variables (sosial factors, design factors and ambient factors) towards dependent variable (impulse buying) which was mediated partially by positive emotion variable on the visitors of Transmart Carrefour Banjarmasin City. For research design, this study used quantitative method by employing an explanatory research. Researchers used primary data obtained from direct distribution questionnaire and utilized purposive sampling method as sampling technique. There were 118 respondents who where involved due to their suitability with study population. Then, the data was analysed by using SEM-PLS method. The results of this study indicated that store's environment influence (social factor, design factor, and ambient factors) had positive and significant effect on visitors' positive emotion and impulse buying. In addition, the indirect influence (social factor, design factor, and ambient factors) which was mediated by positive emotion on impulsive purchases and positive emotion was considered to be partial mediator variable.
\end{abstract}

\section{Keywords: Store Environment, Positive Emotion, Impulse Buying, Consumer Behaviour}

\begin{abstract}
ABSTRAK
Tujuan penelitian ialah untuk mengetahui pengaruh variabel independen yaitu faktor sosial, faktor desain, dan faktor ambient terhadap variabel dependen yaitu pembelian impulsif dan dimediasi secara parsial oleh variabel emosi positif pada pengunjung Transmart Carrefour Kota Banjarmasin. Penelitian ini merupakan jenis penelitian explanatory research dengan pendekatan kuantitatif. Sampel dalam penelitian ini sebanyak 118 responden melalui kuesioner secara langsung kepada pengunjung yang sesuai dengan populasi penelitian. Penarikan sampel dalam penelitian ini menggunakan purposive sampling dan analisis data dalam penelitian ini menggunakan metode SEM-PLS. Hasil penelitian ini menunjukkan adanya pengaruh yang signifikan dan arah hubungan yang positif dari lingkungan toko yang meliputi faktor sosial, faktor desain dan faktor ambient baik secara langsung maupun secara tidak langsung melalui emosi positif terhadap pembelian impulsif. Dalam penelitian ini menunjukkan bahwa emosi positif merupakan variabel mediasi secara parsial.
\end{abstract}

Keywords: Store Environment, Positive Emotion, Impulse Buying, Consumer Behaviour 


\section{PENDAHULUAN}

Pada perkembangan usaha di era milenium sekarang, usaha ritel di Indonesia semakin marak salah satunya bisnis ritel modern. Ritel sendiri dapat diartikan sebagai rantai distribusi akhir dari suatu penjualan produk barang maupun jasa yang dilakukan secara langsung kepada konsumen akhir guna memenuhi kebutuhan mereka secara pribadi bukan untuk bisnis (Winarno, 2015). Ritel terbagi dua yaitu ritel tradisional dan ritel modern (Soliha, 2008).

Ritel modern berkembang secara pesat dilandasi oleh perkembangan perekonomian, teknologi, dan lifestyle yang dimiliki oleh masyarakat Indonesia yang menuntut kenyamanan lebih dalam melakukan perbelanjaan (Martinus, 2011). Hal inilah yang dijadikan peluang oleh ritel modern.

Salah satu ritel modern yang menangkap peluang ini adalah Transmart Carrefour Kota Banjarmasin yang bisnis ritelnya berkembang secara pesat (Rahman, 2018). Transmart Carrefour Kota Banjarmasin hadir sebagai destinasi kebutuhan berbelanja dengan menerapkan konsep yang lebih modern didalam kegiatan berbelanja dengan menggabungkan hypermarket, entertaintment serta food dan fashion menjadi satu di dalam kawasan berintegrasi.

Ritel berhubungan sangat erat dengan lingkungan toko, faktanya bahwa 70 persen dari pembelian merupakan pembelian di luar rencana atau pembelian yang tidak terencana sebelumnya (Dunne \& Lusch, 2005). Mattila dan Wirtz (2006) lingkungan toko yang sangat menstimulasi dan menyenangkan mengarah pada peningkatan pembelian impulsif. Lingkungan toko salah satu kondisi yang menjadi pendorong konsumen dalam memutuskan untuk melakukan pembelanjaan. Lingkungan toko memiliki tiga komponen dasar yaitu faktor sosial, faktor desain, dan faktor ambient yang dapat menciptakan suatu rangsangan pada kondisi emosional yang akan mendorong atau menggerakkan pelanggan untuk membeli lebih banyak barang di luar yang sebelumnya mereka rencanakan.

Pembelian impulsif ialah suatu tindakan membeli yang secara sadar tidak diakui sebagai hasil dari tindakan konsumen dalam niat membeli yang terbentuk dari sebelum maupun sesudah memasuki toko atau bisa dibilang pembelian secara spontan atau pembelian di luar rencana (Mowen \& Minor, 2002) Salah satu faktor yang menyebabkan pembelian impulsif yaitu seperti pengaruh display, promosi, dan desain rak belanja untuk menciptakan suatu kebutuhan baru konsumen (Utami, 2011). Hetharie (2012) dan Wusko (2014) menyatakan peranan karyawan merupakan salah satu faktor yang menyebabkan pembelian impulsif. Sedangkan Mattila (2006) menyatakan bahwa tingkat keramaian pengunjung atau karyawan secara simultan mempengaruhi pembelian tidak direncanakan. Pembelian yang dilakukan di supermarket 75 persennya merupakan tindakan pembelian secara tidak terencana (Negara dan Dharmmesta, 2003).

Dalam penelitian ini selain faktor eksternal yaitu lingkungan toko yang dapat mempengaruhi pembelian tidak terencana adalah faktor internal dalam diri konsumen yaitu emosi. Emosi yang terdiri dari afeksi dan mood merupakan faktor penting dalam sebuah pengambilan keputusan konsumen.

Emosi positif merupakan keadaan yang mempengaruhi suasana hati yang akan menimbulkan aksi atau tindakan termasuk perilaku pembelian impulsive (Park \& Lennon, 2006). Emosi positif yang ada pada diri konsumen dapat mendorong untuk melakukan pembelian suatu produk dengan segera tanpa adanya perencanaan sebaliknya emosi negatif bisa mendorong konsumen untuk enggan membeli produk secara impulsif (Premananto, 2007).

Memaksimalkan lingkungan toko yang mencakup sosial factors, design factors, dan ambient factors yang ada pada Transmart Carrefour Kota Banjarmasin dapat meningkatkan jumlah kunjungan dan peningkatan jumlah pembelian melalui pembelian impulsif. Dari penjelasan yang telah dipaparkan maka rumusan masalah yang ada pada penelitian ini sebagai berikut:

(1) Apakah Social Factors berpengaruh terhadap Emosi Positif?

(2) Apakah Social Factors berpengaruh terhadap Impulse Buying? 
(3) Apakah Design Factors berpengaruh terhadap Emosi Positif?

(4) Apakah Design Factors berpengaruh terhadap Impulse Buying?

(5) Apakah Ambient Factors berpengaruh terhadap Emosi Positif?

(6) Apakah Ambient Factors berpengaruh terhadap Impulse Buying?

(7) Apakah Emosi Positif berpengaruh terhadap Impulse Buying?

\section{KAJIAN PUSTAKA \\ Ritel Modern}

Ritel modern hadir pertama kali di Indonesia pada saat Toserba Sarinah didirikan tahun 1962. Di era tahun 1970 sampai 1980 format bisnis ini kemudian terus berkembang sampai pada tahun 1990an masuk perusahaan ritel asing di Indonesia. Ritel modern dapat diartikan sebagai usaha kegiatan jual beli produk secara eceran yang langsung didistribusikan kepada konsumen akhir dengan harga yang tidak bisa ditawar lagi atau harga nett. Menurut Ma'aruf (2006) ritel modern di Indonesia terbagi beberapa macam salah satunya adalah hypermarket.

\section{Perilaku Konsumen}

Perilaku konsumen merupakan kegiatan yang sangat erat kaitannya dengan proses pembelian barang maupun jasa. (Engel et al, 2008) menyatakan bahwa perilaku konsumen merupakan tindakan-tindakan yang secara langsung terlibat pada saat proses konsumen memperoleh, menggunakan, menghabiskan suatu produk ataupun jasa. Sedangkan menurut Kotler (2009) perilaku konsumen diartikan sebagai tindakan individu, kelompok maupun organisasi dalam memilih lantas membeli kemudian menggunakan dan bagaimana barang ataupun jasa dapat memuaskan kebutuhan mereka.

\section{Store Environment}

Lingkungan toko ialah suatu aspek fisik dan tempat yang konkrit dari lingkungan yang di dalamnya merupakan kegiatan konsumen seperti warna, suara, dan penerangan (Mowen \& Minor, 2002). Peter dan Olson (2009) menguraikan bahwa lingkungan (environment) merupakan karakteristik fisik dan sosial dari dunia eksternal konsumen yang ada di dalam lingkungan toko. Baker (2002) dalam Singh (2006) lingkungan toko dibagi menjadi beberapa elemen meliputi social factors, design factors dan ambient factors.

\section{Emosi Positif}

Emosi merupakan suatu peristiwa dan kondisi lingkungan yang dapat menimbulkan dan memicu emosi seseorang. Solomon (2007) mengemukakan bahwa suasana hati konsumen atau emosi dapat memiliki dampak besar pada keputusan pembelian konsumen termasuk pada perilaku pembelian impulsif. Emosi positif merupakan keadaan yang mempengaruhi suasana hati yang akan menimbulkan aksi atau tindakan termasuk perilaku pembelian impulsif (Park \& Lennon, 2006).

\section{Impulse Buying}

Impulse buying atau pembelian impulsif disebut juga sebagai pembelian yang secara spontan. Rook (1987) dan Hausman (2000) mendefinisikan bahwa pembelian impulsif terjadi ketika konsumen mengalami kejadian secara mendadak yang dapat memunculkan dorongan yang sangat kuat dalam melakukan pembelian dengan segera. Utami (2012) menyatakan bahwa ada empat tipe pembelian impulsif yaitu pure impulse, reminder impulse, suggestion impulse dan planned impulse.

\section{METODE PENELITIAN}

Jenis penelitian yang digunakan dalam penelitian ini adalah explanatory research atau penelitian penjelasan dengan pendekatan kuantitatif yang mendeskripsikan secara kuantitatif kecenderungan-kecenderungan, perilaku-perilaku atau opini-oponi dari suatu populasi dengan meneliti sampel populasi tersebut (Creswell, 2010). Jenis penelitian tersebut sesuai dengan tujuan penelitian yang akan menjelaskan mengenai pengaruh antar variabel yang diperoleh dari fakta-fakta yang ada untuk mengumpulkan data-data dan informasi yang dibutuhkan dalam penelitian ini.

Sumber data dikumpulkan dengan data primer yang didapat dengan teknik pengumpulan data yaitu survei dengan menggunakan angket (kuesioner). Kuesioner tersebut berisi sejumlah pertanyaan maupun pernyataan tentang tanggapan atas persepsi pengunjung Transmart Carrefour Kota 
Banjarmasin yang disebarkan secara langsung oleh peneliti kepada pengunjung yang sesuai dengan kriteria populasi.

Pengunjung Transmart Carrefour Kota Banjarmasin merupakan populasi dalam penelitian ini dengan jumlah sampel sebanyak 118 responden yang sesuai dengan perhitungan sampel dan terisi sesuai dengan karakteristik sampel.

\section{Tabel 1. Karakteristik Responden}

\begin{tabular}{lcc}
\hline $\begin{array}{l}\text { Karakteristik } \\
\text { Demografis }\end{array}$ & $\begin{array}{c}\text { Frekuensi } \\
(\mathbf{f})\end{array}$ & $\begin{array}{c}\text { Persentasi } \\
(\%)\end{array}$ \\
\hline Jenis Kelamin & 58 & 49.15 \\
Laki-laki & 60 & 50.85 \\
Perempuan & & \\
Usia & 12 & 10.17 \\
17-23 Tahun & 19 & 16.10 \\
$>$ 22-29 Tahun & 27 & 22.89 \\
$>$ 29-35 Tahun & 34 & 28.81 \\
$>$ 35-41 Tahun & 15 & 12.71 \\
$>$ 41-47 Tahun & 5 & 4.24 \\
$>$ 47-53 Tahun & 4 & 3.39 \\
$>$ 53-59 Tahun & 2 & 1.69 \\
$>$ 59-65 Tahun & & \\
Pekerjaan & 30 & 25.43 \\
PNS & 35 & 29,66 \\
Pengawai Swasta & 11 & 9,32 \\
TNI/Polri & 24 & 20,34 \\
Wirausaha & 18 & 15,25 \\
Lain-lain &
\end{tabular}

Sumber: Data Primer (2019)

Metode SEM-PLS dengan alat analisis SmartPLS digunakan sebagai pengolahan data dalam penelitian ini.

Penelitian ini menggunakan variabel eksogen (X) meliputi Faktor Sosial sebagai variabel X1, Faktor Desain sebagai variabel X2 dan Faktor Ambient sebagai variabel X3. Variabel intervening (Y1) yaitu Emosi Positif sebagai variabel (Y1) dan variabel endogen (Y2) ialah Impulse Buying sebagai variabel (Y2).

Tabel 2. Outer Loadings

\begin{tabular}{|l|r|r|r|}
\hline & \multicolumn{1}{|l|}{$\begin{array}{l}\text { Original } \\
\text { Sample } \\
(\text { O })\end{array}$} & $\begin{array}{l}\text { Standard } \\
\text { Deviation } \\
(\text { STDEV })\end{array}$ & \multicolumn{1}{|l|}{$\begin{array}{l}\text { T Statistics } \\
(\mid \text { OSTERR } \mid)\end{array}$} \\
\hline $\mathrm{X} 1.1<-\mathrm{X} 1$ & 0,941 & 0,014 & 68,352 \\
\hline $\mathrm{X} 1.2<-\mathrm{X} 1$ & 0,932 & 0,015 & 62,712 \\
\hline $\mathrm{X} 2.1<-\mathrm{X} 2$ & 0,895 & 0,026 & 34,380 \\
\hline $\mathrm{X} 2.2<-\mathrm{X} 2$ & 0,931 & 0,015 & 60,658 \\
\hline $\mathrm{X} 2.3<-\mathrm{X} 2$ & 0,910 & 0,023 & 39,032 \\
\hline
\end{tabular}

\begin{tabular}{|l|l|l|r|}
\hline $\mathrm{X} 2.4<-\mathrm{X} 2$ & 0,913 & 0,019 & 48,213 \\
\hline $\mathrm{X} 2.5<-\mathrm{X} 2$ & 0,907 & 0,027 & 33,964 \\
\hline $\mathrm{X} 3.1<-\mathrm{X} 3$ & 0,909 & 0,019 & 48,110 \\
\hline $\mathrm{X} 3.2<-\mathrm{X} 3$ & 0,909 & 0,026 & 35,712 \\
\hline $\mathrm{X} 3.3<-\mathrm{X} 3$ & 0,938 & 0,020 & 47,412 \\
\hline $\mathrm{X} 3.4<-\mathrm{X} 3$ & 0,839 & 0,054 & 15,537 \\
\hline $\mathrm{X} 3.5<-\mathrm{X} 3$ & 0,922 & 0,020 & 46,961 \\
\hline $\mathrm{Y} 1.1<-\mathrm{Y} 1$ & 0,960 & 0,012 & 83,355 \\
\hline $\mathrm{Y} 1.2<-\mathrm{Y} 1$ & 0,964 & 0,009 & 106,242 \\
\hline $\mathrm{Y} 2.1<-\mathrm{Y} 2$ & 0,882 & 0,025 & 35,698 \\
\hline $\mathrm{Y} 2.2<-\mathrm{Y} 2$ & 0,853 & 0,028 & 30,952 \\
\hline $\mathrm{Y} 2.3<-\mathrm{Y} 2$ & 0,833 & 0,034 & 24,737 \\
\hline $\mathrm{Y} 2.4<-\mathrm{Y} 2$ & 0,837 & 0,034 & 24,563 \\
\hline
\end{tabular}

Sumber: Hasil Analisis PLS, 2019

Tabel 2. menjabarkan nilai faktor loading dari setiap indikator dengan kriteria jika nilai faktor loading di atas nilai 0,7 maka dinyatakan hasil penelitian ialah valid. Tetapi bisa dikatakan valid apabila nilai faktor loading masih di atas nilai 0,5 dan nilai tersebut tidak di bawah nilai tersebut. Tabel 2 menunjukkan hasil faktor loading dari setiap indikator mendapatkan hasil lebih besar dari nilai 0,7 yang mana hasil tersebut dapat dikatakan valid.

Tabel 3. Nilai Discriminant Validity (Cross Loading)

\begin{tabular}{|l|l|l|l|l|l|}
\hline & $\mathrm{X} 1$ & $\mathrm{X} 2$ & $\mathrm{X} 3$ & $\mathrm{Y} 1$ & $\mathrm{Y} 2$ \\
\hline $\mathrm{X} 1.1$ & $\mathbf{0 , 9 4 1}$ & 0,835 & 0,681 & 0,744 & 0,811 \\
\hline X1.2 & $\mathbf{0 , 9 3 2}$ & 0,719 & 0,595 & 0,695 & 0,750 \\
\hline X2.1 & 0,731 & $\mathbf{0 , 8 9 5}$ & 0,677 & 0,645 & 0,748 \\
\hline X2.2 & 0,753 & $\mathbf{0 , 9 3 1}$ & 0,626 & 0,667 & 0,741 \\
\hline X2.3 & 0,783 & $\mathbf{0 , 9 1 0}$ & 0,544 & 0,742 & 0,777 \\
\hline X2.4 & 0,750 & $\mathbf{0 , 9 1 3}$ & 0,556 & 0,714 & 0,734 \\
\hline X2.5 & 0,767 & $\mathbf{0 , 9 0 7}$ & 0,649 & 0,687 & 0,802 \\
\hline X3.1 & 0,610 & 0,561 & $\mathbf{0 , 9 0 9}$ & 0,603 & 0,655 \\
\hline X3.2 & 0,623 & 0,596 & $\mathbf{0 , 9 0 9}$ & 0,594 & 0,662 \\
\hline X3.3 & 0,649 & 0,618 & $\mathbf{0 , 9 3 8}$ & 0,600 & 0,645 \\
\hline X3.4 & 0,556 & 0,589 & $\mathbf{0 , 8 3 9}$ & 0,528 & 0,629 \\
\hline X3.5 & 0,642 & 0,658 & $\mathbf{0 , 9 2 2}$ & 0,626 & 0,697 \\
\hline Y1.1 & 0,721 & 0,721 & 0,660 & $\mathbf{0 , 9 6 0}$ & 0,731 \\
\hline Y1.2 & 0,758 & 0,740 & 0,600 & $\mathbf{0 , 9 6 4}$ & 0,809 \\
\hline Y2.1 & 0,736 & 0,745 & 0,649 & 0,721 & $\mathbf{0 , 8 8 2}$ \\
\hline Y2.2 & 0,711 & 0,680 & 0,489 & 0,714 & $\mathbf{0 , 8 5 3}$ \\
\hline Y2.3 & 0,678 & 0,702 & 0,718 & 0,639 & $\mathbf{0 , 8 3 3}$ \\
\hline Y2.4 & 0,717 & 0,715 & 0,618 & 0,654 & $\mathbf{0 , 8 3 7}$ \\
\hline Sum & (1) & \\
\hline
\end{tabular}

Sumber: Hasil Analisis PLS, 2019 
Pada Tabel 3 dapat diketahui bahwa semua indikator dari masing-masing variabel dinyatakan telah memenuhi discriminant validit, nilai tersebut dapat dilihat pada angka yang dicetak tebal dikarenakan hasil dalam penelitian nilai outer loadings memiliki nilai terbesar untuk variabel yang dibentuk dan tidak untuk variabel lainnya.

Tabel 4. Nilai R-Square

\begin{tabular}{|l|l|r|}
\hline No & Variabel & R-Square \\
\hline 1 & Y1 & 0.6543 \\
\hline 2 & Y2 & 0.8066 \\
\hline
\end{tabular}

Sumber: Hasil Analisis PLS, 2019

Nilai $R$-square dapat dilihat pada Tabel 4 di atas yang mana nilai $R$-square untuk variabel (Y1) yaitu Emosi Positif mendapatkan nilai sebesar 0,6543 dengan persentase sebesar 65,43\% bahwa variabel Emosi Positif (Y1) dapat dipengaruhi oleh variabel $(\mathrm{X})$ meliputi Faktor Sosial (X1), Faktor Desain (X2), dan Faktor Ambient (X3). Sedangkan sisanya sebesar 23,93\% dipengaruhi oleh variabel lain di luar penelitian. Nilai $R$-square (Y2) sebesar 0,8066 diketahui variabel Impulse Buying (Y2) dipengaruhi oleh variabel Faktor Sosial (X1), Faktor Desain (X2), Faktor Ambient (X3) dan variabel Emosi Positif (Y1) sebesar 80,66\% sedangkan sisanya $19,34 \%$ dipengaruhi oleh variabel lainnya di luar yang diteliti.

Tabel 5. Path Coefficient

\begin{tabular}{|l|c|r|r|c|}
\hline $\begin{array}{c}\text { Hubungan } \\
\text { Variabel }\end{array}$ & $\begin{array}{c}\text { Original } \\
\text { Sample } \\
(O)\end{array}$ & $\begin{array}{c}\text { Standard } \\
\text { Deviatio } \\
n \\
(\text { STDEV })\end{array}$ & $\begin{array}{c}\text { T Statistics } \\
(\mid \text { O/STER } \\
R \mid)\end{array}$ & $\begin{array}{c}\mathrm{p}- \\
\text { value }\end{array}$ \\
\hline $\mathrm{X} 1$-> Y1 & 0,373 & 0,116 & 3,206 & 0,002 \\
\hline $\mathrm{X} 1$-> Y2 & 0,272 & 0,097 & 2,800 & 0,006 \\
\hline $\mathrm{X} 2$-> Y1 & 0,329 & 0,102 & 3,225 & 0,002 \\
\hline $\mathrm{X} 2$-> Y2 & 0,303 & 0,102 & 2,977 & 0,004 \\
\hline $\mathrm{X} 3$-> Y1 & 0,179 & 0,079 & 2,256 & 0,026 \\
\hline $\mathrm{X} 3$-> Y2 & 0,180 & 0,068 & 2,640 & 0,009 \\
\hline Y1 -> Y2 & 0,244 & 0,091 & 2,682 & 0,008 \\
\hline
\end{tabular}

Sumber: Hasil Analisis PLS, 2019

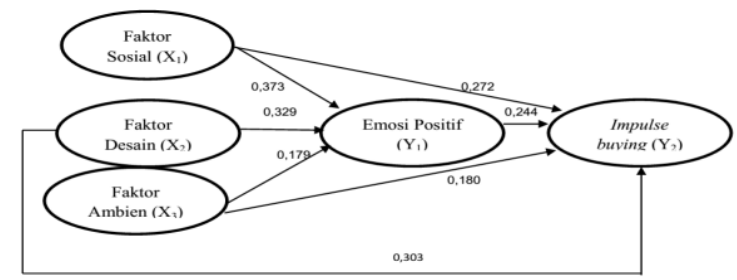

Gambar 1. Model Pengujian Hipotesis

Sumber: Hasil Pengujian Hipotesis
Berdasarkan pada Tabel 5 didapatkan hasil sebagai berikut:

Persamaam struktural yang didapat adalah :

$\mathrm{Y} 1=0,373 \mathrm{X}_{1}+0,329 \mathrm{X}_{2}+0,179 \mathrm{X}_{3}$

$\mathrm{Y} 2=0,272 \mathrm{X}_{1}+0,303 \mathrm{X}_{2}+0,180 \mathrm{X}_{3}+0,244 \mathrm{Y}_{1}$

\section{PEMBAHASAN}

Dari 118 responden yang sesuai dengan kriteria penelitian yang pada akhirnya didapatkan $t$ tabel sebesar 1,960. Tabel 5 memberikan output estimasi untuk pengujian model struktural sebagai berikut:

H1: Faktor Sosial Berpengaruh signifikan terhadap Emosi Positif. Pengujian variabel X1 terhadap variabel $\mathrm{Y} 1$ menghasilkan nilai koefisien jalur sebesar 0,373 dan nilai $t$ diperoleh sebesar 3,206. Kedua nilai tersebut lebih besar dari nilai yang sudah ditentukan yaitu nilai $t$ tabel $(1,960)$ atau nilai p-value lebih kecil dari nilai $0,05 \quad(0,002<0,05)$. Dapat diketahui bahwa variabel X1 dinyatakan memiliki pengaruh yang signifikan terhadap variabel Y1, maka untuk Hipotesis Pertama dapat diterima.

Penelitian ini mendukung penelitian Baker, et al., (2002); Semuel (2005); Xu (2007); Hetharie (2012) yang membuktikan bahwa Faktor Sosial berpengaruh terhadap Emosi Positif. Liaw (2007) dan Mattila and Wirtz (2008) Faktor Sosial yang meliputi peran karyawan dan kepadatan pengunjung menghasilkan pengaruh yang positif serta memiliki hubungan yang signifikan terhadap Emosi Positif.

Nilai rata-rata dari masing-masing indikator diperoleh nilai 3,81 untuk variabel Faktor Sosial dan variabel Emosi Positif bernilai 3,65 dari total skala likert. Dari penjabaran sebelumnya dapat dinyatakan bahwa responden setuju Faktor Sosial memiliki pengaruh terhadap Emosi Positif, sehingga semakin baik Faktor Sosial terutama peran karyawan yang ada pada toko, maka akan meningkatkan Emosi Positif pengunjung Transmart Carrefour Kota Banjarmasin.

H2: Faktor Sosial Berpengaruh signifikan terhadap Impulse Buying. Pengujian variabel 
$\mathrm{X} 1$ terhadap variabel $\mathrm{Y} 2$ diperoleh nilai koefisien jalur sebesar 0,272 dan nilai t sebesar 2,800 . Nilai ini menunjukkan lebih besar dari $\mathrm{t}$ tabel $(1,960)$ atau p-value lebih kecil dari 0,05 $(0,006<0,05)$. Hasil tersebut diketahui bahwa variabel $\mathrm{X} 1$ berpengaruh secara signifikan terhadap Y2 sehingga Hipotesis ke dua dapat diterima.

Sesuai dengan penelitian Peter dan Olson (1991); Han et al., (1991); Park and Lennon (2006) Faktor Sosial berpengaruh terhadap Impulse Buying. Penelitian tersebut mendukung penelitian Inggrid (2016) yang menyatakan bahwa faktor sosial melalui elemennya seperti karyawan toko yang berpenampilan menarik, ramah dan cepat tanggap dalam melayani pengunjung serta cukupnya jumlah karyawan pada toko maka pembelian impulsif akan meningkat. Matilla dan Wirtz (2006) juga berpendapat bahwa terdapat pengaruh lingkungan toko terhadap pembelian impulsif dan tingkat kepadatan atau keramaian juga memiliki pengaruh terhadap pembelian impulsif.

Penelitian ini memperoleh nilai rata-rata dari masing-masing indikator dalam variabel Faktor Sosial bernilai 3,81 dan variabel Impulse Buying bernilai 3,74. Dapat disimpulkan dari hasil yang didapat bahwa jawaban responden setuju Faktor Sosial memiliki pengaruh terhadap Impulse Buying. Semakin bagus Faktor Sosial maka mampu meningkatkan Impulse Buying. .

H3: Faktor Desain berpengaruh signifikan terhadap Emosi Positif. Pengujian variabel X2 terhadap Y1 menghasilkan nilai koefisien jalur sebesar 0,329 dan nilai t sebesar 3,225. Kedua nilai tersebut dapat diketahui lebih besar dari nilai $t$ tabel 1,960 atau p-value lebih kecil dari $0,05 \quad(0,002<0,05)$. Hasilnya ialah bahwa variabel $\mathrm{X} 2$ berpengaruh secara signifikan terhadap Y1 sehingga Hipotesis ke tiga dapat diterima.

Hasil ini mendukung penelitian $\mathrm{Xu}$ (2007) dan Chang, et al. (2014) yang membuktikan bahwa Faktor Desain memiliki pengaruh terhadap Emosi Positif. Baker, et al., (2002) menguraikan tentang Faktor Desain seperti hal yang dirasakan oleh konsumen akan menciptakan kesan yang beragam pada setiap konsumen yang menerimanya melalui berbagai aspek seperti aspek dekorasi, aspek warna, aspek tata letak, aspek tata produk meliputi display dan aspek tanda-tanda meliputi petunjuk produk, harga dan papan petunjuk discount (Xu, 2007). Liaw (2007) dan Kusumowidagdo (2010) juga berpendapat bahwa warna dapat mempengaruhi emosi konsumen secara langsung. Desain toko yang dapat mencerminkan produk-produk di dalam toko akan menimbulkan lingkungan yang nyaman, sehingga lebih meningkatkan ketertarikan konsumen untuk datang dan berbelanja di toko tersebut (William, 2013).

Penelitian ini memperoleh nilai rata-rata dari masing-masing indikator dalam variabel Faktor Desain bernilai 3,87 dan variabel Emosi Positif bernilai 3,65. Diketahui nilai variabel Faktor Desain dan Emosi Positif tersebut menghasilkan jawaban responden yang menyatakan setuju tentang Faktor Desain memiliki pengaruh terhadap Emosi Positif, sehingga semakin baik Faktor Desain maka akan meningkatkan Emosi Positif pengunjung Transmart Carrefour Kota Banjarmasin.

H4: Faktor Desain berpengaruh signifikan terhadap Impulse Buying. Hasil pengujian variabel X2 terhadap Y2 diperoleh nilai sebesar 0,303 dari nilai koefisien jalur dan sebesar 2,977 dari nilai t. Nilai tersebut diketahui lebih besar dari t tabel 1,960 atau p-value lebih kecil dari $0,05(0,004<0,05)$. Hasil ini membuktikan bahwa variabel $\mathrm{X} 2$ berpengaruh secara signifikan terhadap Y2 sehingga Hipotesis ke empat dapat diterima.

Hasil ini sependapat dengan Baker, et al., (2002) menyatakan melalui aspek pada lingkungan toko meliputi aspek warna, aspek arsitektur, aspek dekorasi, dan aspek lainnya yang berkaitan dengan Faktor Desain mampu menimbulkan stimulus yang dapat memicu atau menggerakkan konsumen dalam pembelian barang yang lebih banyak diluar rencana mereka sebelumnya. Hal ini juga didukung oleh penelitian Xu (2007) dan Liaw (2007). Berman and Evans (1992); Engel, et al. (1993); Peter dan Olson (2000); Assael (2002) dan Haqqul (2012). Engel, et al. (1994) menegaskan bahwa warna yang hangat seperti merah atau kuning 
tampak lebih efektif pada orang yang menarik secara fisik. Hal ini Transmart Carrefour Kota Banjarmasin menggunakan warna merah, dengan indikasi warna tersebut dapat menarik perhatian konsumen yang berbelanja untuk memunculkan pembelian impulsif.

Dalam penelitian ini diperoleh bahwa nilai rata-rata dari masing-masing indikator dalam variabel Faktor Desain bernilai 3,87 dan variabel Impulse Buying bernilai 3,74 dari total skala Likert. Hasil ini menyatakan bahwa responden menjawab setuju Faktor Desain memiliki pengaruh terhadap Impulse Buying, sehingga semakin baik Faktor Desain yang ada pada Transmart Carrefour Kota Banjarmasin, maka akan dapat meningkatkan Impulse Buying.

H5: Faktor Ambient berpengaruh signifikan terhadap Emosi Positif. Hasil pengujian variabel X3 terhadap Y1 menghasilkan nilai sebesar 0,179 yaitu nilai koefisien jalur dan sebesar 2,256 yaitu nilai t. Nilai di atas lebih besar dari t tabel 1,960 atau p-value lebih kecil dari $0,05(0,026<0,05)$. Dapat diketahui bahwa variabel $\mathrm{X} 3$ berpengaruh secara signifikan terhadap Y1 sehingga Hipotesis ke lima dapat diterima.

Hasil yang diperoleh mendukung penelitian Chang, et al. (2014) Ambient Factors mempunyai pengaruh terhadap Positive Emotion. Utami (2006); Xu (2007) dan Yu and Pow (2010) bahwa Faktor Ambient yang mengacu pada suhu, pencahayaan, kebisingan, musik, dan aroma dapat mempengaruhi emosi positif. Quartier, et al. (2008) menyatakan bahwa pencahayaan dapat mempengaruhi mood konsumen dan berpengaruh pada perilaku konsumen. Sedangkan penelitian Hawkins, et al. (2000) menyatakan musik dapat memiliki dampak besar terhadap lingkungan toko sehingga musik dapat meningkatkan respon emosional yang positif. Levy and Weitz (2002) dan Solomon (2007) aroma tertentu dapat membangkitkan emosi atau membuat perasaan menenangkan dan menempatkan pelanggan dalam suasana hati yang lebih baik lagi. Aroma secara langsung mempengaruhi persepsi pembeli dan berpengaruh secara signifikan atas terbentuknya emosi konsumen.
Penelitian ini memperoleh nilai rata-rata dari masing-masing indikator dalam variabel Faktor Ambient bernilai 3,90 dan variabel Emosi Positif bernilai 3,65. Nilai tersebut memperlihatkan mengenai jawaban setujunya responden bahwa Faktor Ambient memiliki pengaruh terhadap Emosi Positif, sehingga semakin baik Faktor Ambient meliputi jenis musik tepat, jenis musik yang membuat pengunjung nyaman, volume musik tepat, pengaturan suhu memberikan kenyamanan, pencahayaan yang tepat dan aroma ruangan toko membuat konsumen nyaman maka akan meningkatkan Emosi Positif pengunjung Transmart Carrefour Kota Banjarmasin.

H6: Faktor Ambient berpengaruh signifikan terhadap Impulse Buying. Hasil pengujian variabel X3 terhadap Y2 diketahui bahwa nilai koefisien jalur sebesar 0,180 dan nilai t sebesar 2,640 . Nilai kedua variabel ini lebih besar dari t tabel 1,960 atau p-value lebih kecil dari 0,05 $(0,009<0,05)$. Dari hasil nilai yang sudah disebutkan ditemukan bahwa hipotesis variabel X3 berpengaruh secara signifikan terhadap Y2 sehingga Hipotesis ke enam dapat diterima.

Temuan penelitian ini mendukung penelitian Haaqqul (2012) dan Inggrid (2016) yang menjelaskan apabila Faktor Ambient dalam toko ditingkatkan maka Impulse Buying akan meningkat. Mowen dan Minor (2002) menyatakan bahwa musik yang diputar dalam tempo lambat akan membuat konsumen meluangkan waktunya lebih lama dan membelanjakan lebih banyak lagi uang mereka, sedangkan musik dengan tempo cepat menyebabkan konsumen lalu lalang dalam toko dipercepat.

Penelitian ini memperoleh nilai rata-rata dari masing-masing indikator dalam variabel Faktor Ambient bernilai 3,90 dan variabel Impulse Buying bernilai 3,74. Hasil nilai tersebut dapat disimpulkan atas jawaban responden yang setuju mengenai Faktor Ambient memiliki pengaruh terhadap Impulse Buying, indikasinya semakin tinggi Faktor Ambient yang ada di dalam toko, maka mampu meningkatkan Impulse Buying. 
H7: Emosi Positif berpengaruh signifikan terhadap Impulse Buying. Hasil pengujian variabel Y1 terhadap Y2 diperoleh nilai koefisien jalur sebesar 0,244 dan nilai t sebesar 2,682. Hasil nilai tersebut dikatakan lebih besar dari t tabel 1,960 atau p-value lebih kecil dari $0,05 \quad(0,008<0,05) \quad$ Penjabaran tersebut membuktikan bahwa variabel Y1 berpengaruh secara signifikan terhadap Y2 sehingga Hipotesis ke tujuh diterima.

Hasil penelitian ini didukung oleh penelitian Hausman (2000) dan Park (2006) yang menyimpulkan kondisi mempengaruhi secara kuat terhadap sebuah tindakan atau keputusan berbelanja di luar perencanaan sebelumnya. Hal ini diperkuat oleh penelitian Semuel (2006) yang menyatakan bahwa respon emosi mempunyai dampak yang positif terhadap perilaku pembelian tidak terencana.

Penelitian ini memperoleh nilai rata-rata dari masing-masing indikator dalam variabel Emosi Positif bernilai 3,65 dan variabel Impulse Buying bernilai 3,74. Nilai yang telah diuraikan menghasilkan jawaban responden bahwa responden setuju tentang Emosi Positif memiliki pengaruh terhadap Impulse Buying, sehingga semakin baik Emosi Positif pada pengunjung Transmart Carrefour Kota Banjarmasin, maka akan dapat meningkatkan Impulse Buying.

\section{Hasil Pengaruh Tidak Langsung}

\begin{tabular}{|c|c|c|c|}
\hline Variabel & $\begin{array}{c}\text { Koefisien } \\
\text { Tidak } \\
\text { Langsung }\end{array}$ & t Hitung & p-Value \\
\hline $\mathrm{X} 1$-> Y1 -> Y2 & 0.091 & 2.001 & 0.048 \\
\hline $\mathrm{X} 2$-> Y1 -> Y2 & 0.080 & 2.006 & 0.047 \\
\hline $\mathrm{X} 3$-> Y1 -> Y2 & 0.044 & 2.047 & 0.043 \\
\hline
\end{tabular}

Sumber: Hasil Analisis Pls,2019

Emosi Positif memediator pengaruh antara Faktor Sosial terhadap Impulse Buying. Variabel X1 terhadap Y2 melalui Y1 dengan diperoleh nilai sebesar 0,091 dinyatakan sebagai nilai koefisien jalur tidak langsung dan nilai sebesar 2,001 sebagai nilai t hitung. Kedua nilai yang sudah diuraikan membuktikan bahwa nilai tersebut lebih besar dari t tabel 1,960 atau p-value lebih kecil daripada $0,05(0,048<0,05)$. Dengan demikian pengaruh tidak langsung Faktor Sosial terhadap Impulse Buying melalui Emosi Positif mempunyai pengaruh yang signifikan. Karena pengaruh secara langsung dan secara tidak langsung kedua variabel itu signifikan, maka variabel Emosi Positif merupakan variabel mediator yang parsial.

Emosi Positif memediator pengaruh antara Faktor Desain terhadap Impulse Buying. Variabel X2 terhadap Y2 melalui Y1 dengan diperoleh nilai sebesar 0,080 dinyatakan sebagai nilai koefisien jalur tidak langsung dan nilai sebesar 2,006 sebagai nilai t hitung. nilai ini membuktikan bahwa nilai tersebut lebih besar dari t tabel 1,960 atau p-value lebih kecil daripada $0,05 \quad(0,048<0,05)$. Hasil ini membuktikan bahwa pengaruh tidak langsung Faktor Desain terhadap Impulse Buying melalui Emosi Positif mempunyai pengaruh yang signifikan. Karena itu pengaruh secara langsung ataupun pengaruh secara tidak langsung dari kedua variabel dinyatakan signifikan, maka variabel Emosi Positif dianggap sebagai variabel mediator yang parsial.

Emosi Positif memediator pengaruh antara Faktor Ambient terhadap Impulse Buying. Variabel X3 terhadap Y2 melalui Y1 menghasilkan nilai sebesar 0,044 sebagai nilai koefisien jalur tidak langsung dan nilai sebesar 2,047 sebagai nilai t hitung yang mana nilai ini lebih besar dari t tabel 1,960 atau p-value lebih kecil dari $0,05(0,043<0,05)$. Dapat disimpulkan bahwa pengaruh tidak langsung Faktor Ambient terhadap Impulse Buying melalui Emosi Positif terbukti mempunyai pengaruh yang signifikan. Karena pengaruh secara langsung dan secara tidak langsung dari kedua variabel dibuktikan signifikan, maka Emosi Positif dinyatakan sebagai variabel mediator yang parsial.

Diketahui dari yang sudah dijabarkan sebelumnya bahwa pengaruh Faktor Sosial, Faktor Desain, Faktor Ambient terhadap Impulse Buying baik itu secara langsung dan secara tidak langsung menghasilkan hasil yang signifikan. Disimpulkan variabel Emosi Positif merupakan variabel mediator yang parsial karena tanpa melalui Emosi Positif pengaruh dari ketiga variabel eksogen terhadap variabel endogen membuktikan bahwa hasil yang didapat signifikan. 


\section{KESIMPULAN DAN SARAN \\ Kesimpulan}

Penelitian ini menguji pengaruh secara langsung dari variabel Faktor Sosial, variabel Faktor Desain, dan variabel Faktor Ambient terhadap variabel Emosi Positif dan variabel Impulse Buying. Diketahui, penelitian ini menemukan bukti yang mana disebutkan bahwa variabel Faktor Sosial, variabel Faktor Desain, dan variabel Faktor Ambient mempunyai pengaruh yang signifikan terhadap variabel Emosi Positif dan variabel Impulse Buying. Dan diketahui juga di luar dari hipotesis penelitian mengenai pengaruh tidak langsung yang menyebutkan bahwa variabel Emosi Positif memediator pengaruh antara variabel Faktor Sosial, variabel Faktor Desain, dan variabel Faktor Ambient terhadap variabel Impulse Buying terbukti signifikan.

\section{Saran}

Sebab itu, untuk penelitian ini dapat diharapkan membantu pihak Transmart Carrefour Kota Banjarmasin dalam pengoptimalan dari lingkungan toko untuk meningkatkan jumlah kunjungan dan peningkatan jumlah pembelian dari para pengunjung.

\section{DAFTAR PUSTAKA}

Astuti, R. D., dan Fillippa, M. 2008. Perbedaan Pembelian Secara Impulsif Berdasarkan Tingkat Kecenderungan, Kategori Produk dan Pertimbangan Pembelian. Jurnal Ichsan Gorontolo. Vol 3, No. 1, pp. 14411456.

Baker, Julie, A. Parasuraman, Dhruv Grewal, and Glenn B. Voss. 2002. The Influence of Multiple Environment Cues on Perceived Merchandise Value and Patronage Intentions. Journal of Marketing. Vol. 66 (April 2002) pp 120-141.

Chang, H., Yan, R., and Eckman, M. 2014. Moderating effects of situational characteristics on impulse buying. International Journal of Retail \& Distribution Management. Vol. 42. No. 4. pp. 298-314
Dunne, P. M., \& Lusch, R. F. 2005. Retailing (5th Ed). Ohio: South Western, A Division of Thomson Learning.

Engel, J., Roger, D. B., \& Paul , W. M. 2008. Perilaku Konsumen. Alih Bahasa: Budyanto. Jilid 1. Jakarta: Binarupa Aksara Publisher.

Hausman, A. 2000. "A Multi-Method Investigation of Consumer Motivations in Impulse Buying Behavior. Journal of Consumer Marketing, Vol. 17, No.5, pp. 403-419

Haqqul, Nur. 2012. "Pengaruh Atmosfer Toko Terhadap Keputusan Pembelian Toko Buku Togamas Cabang Malang”. Tesis. Universitas Islam Negeri Maulana Malik Ibrahim. Malang.

Hawkins, Dell., Roger J. Best, and Kenneth A. Coney. 2000. "Consumer Behaviour: Building Marketing Strategy”. New York: McGraw-Hill.

Hetharie, J. A. 2012. "Impulse Buying Tendency: Studi Pada Konsumen Matahari Departement Store Kota Ambon". Iqtisboduna. Vol. 8, No. 2. 2012.

Ma'aruf, Hendri. 2006. "Pemasaran Ritel". Jakarta: PT. Gramedia Pustaka Utama.

Matilla, S. Anna and Fochen Wirtz. 2006. "The Role Store Environmental Stimulation and Factors on Impulse Purchasing". Journal of Service Marketing: pp. 562-567.

Mowen, John C. dan Michael Minor. 2002 "Perilaku Konsumen". Alih Bahasa: Dwi Kartini Yahya. Jilid 2. Jakarta: Penerbit Erlangga.

Negara, D. Jaya and Basu Swastha Dharmmesta. 2003. "Normative Moderators of Impulse Buying Behaviour". Gadjah Mada Internasional Journal of Bussiness January 2003. Vol. 3 No. 1, pp. 1-14. 
Park, E. J., Kim, Eun Yong., and Forney, J. C. 2005. "A Structural Model of Fashion Oriented Impulse Buying Behavior". Journal of Fashion Marketing and Management. Vol. 10. N0. 4. pp. 433-446.

Quartier, Katelijn, Christiaans, Henry and Van Cleempoel. 2009. "Retail Design: Lighting As An Atmospheric Tool, Creating Experiences which Influence Consumer's Mood and Behaviour in Commercial Space". Design Research Society Conference 2008. Sheefield Hallam University, Sheffield UK, 16-19 July 2008.

Semuel, Hatane. 2005. "Respons Lingkungan Berbelanja Sebagai Stimulus Pembelian Tidak Terencana pada Toko Serba Ada (Toserba)". Jurnal Manajemen dan Kewirausahaan. Vol. 7 No. 2 September 2005, hal. 152-170.

Sinaga, Inggrid., Suharyono., dan Srikandi Kumadji. 2012. "Stimulus Store Environment dalam Menciptakan Emotion Responden dan Pengaruhnya Tehradap Impulse Buying”. Administrasi Bisnis. 1(2).

Solomon, Michael R. 2007. "Consumer Behaviour: Buying, Having, and Being”. Seventh Edition. New Jersey: Pearson Prentice Hall.

Utami, Christina Whidya. 2011. "Manajemenritel: Strategi dan Implemtasi Operasional Bisnis Ritel Modern di Indonesia". Edisi 2. Jakarta: Salemba Empat.

Watson, D. dan Tellegen, A. 1985. "Toward a consensus structure of mood. Psychological Bulletin”. Vol. 98. No. 2. PP 35-219.

William, Jebarajakirthy. 2013. "Significant of Visual Merchandising As a Weapon of Strategic Marketing: In Sri Lanka Food Retailing". Internasional Journal of Management Research and Review, 3(3), pp: 2355-2363.
Winarno, A.P. 2015. "Pengaruh Store Atmospherics dan In Store Promotion Terhadap Impulse Buying Konsumen Di Supermarket Bilka Surabaya (Doctoral Dissertation)". Widya Mandala, Catholic University Surabaya.

Wusko. Any Urwatul. 2014. "Pengaruh Kualitas Pelayanan Terhadap Kepuasan Pengguna Jasa Pada Rumah Sakit Umum Daerah Bangil Kabupaten Pasuruan". Jurnal Ketsa Bisnis Vol.1, No. 1. Hal:15-28.

$\mathrm{Xu}$, Yingjiao. 2007. "Impact of Store Environment on Adult Generation $Y$ Consumers Impulse Buying". Journal of Shopping Center Research. Vol. 14 No 1. pp. 39-56. 